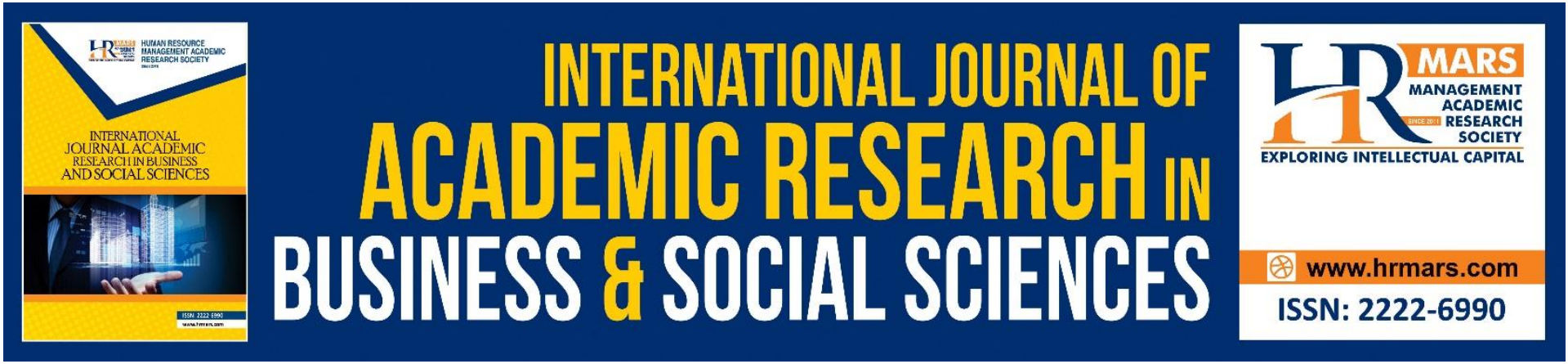

\title{
Fostering Innovation in Education Industry: The Mediating Role of Knowledge Transfer
}

Siti Nurellyza Suria Ab. Rahim, Nor Lelawati Jamaludin, Siti Suriawati Isa

To Link this Article: http://dx.doi.org/10.6007/IJARBSS/v12-i1/12031

DOI:10.6007/IJARBSS/v12-i1/12031

Received: 13 November 2021, Revised: 10 December 2021, Accepted: 30 December 2021

Published Online: 19 January 2022

In-Text Citation: (Rahim et al., 2022)

To Cite this Article: Rahim, S. N. S. A., Jamaludin, N. L., \& Isa, S. S. (2022). Fostering Innovation in Education Industry: The Mediating Role of Knowledge Transfer. International Journal of Academic Research in Business and Social Sciences, 12(1), 1306-1322.

Copyright: @ 2022 The Author(s)

Published by Human Resource Management Academic Research Society (www.hrmars.com)

This article is published under the Creative Commons Attribution (CC BY 4.0) license. Anyone may reproduce, distribute, translate and create derivative works of this article (for both commercial and non0-commercial purposes), subject to full attribution to the original publication and authors. The full terms of this license may be seen at: http://creativecommons.org/licences/by/4.0/legalcode

Vol. 12, No. 1, 2022, Pg. $1306-1322$

Full Terms \& Conditions of access and use can be found at http://hrmars.com/index.php/pages/detail/publication-ethics 


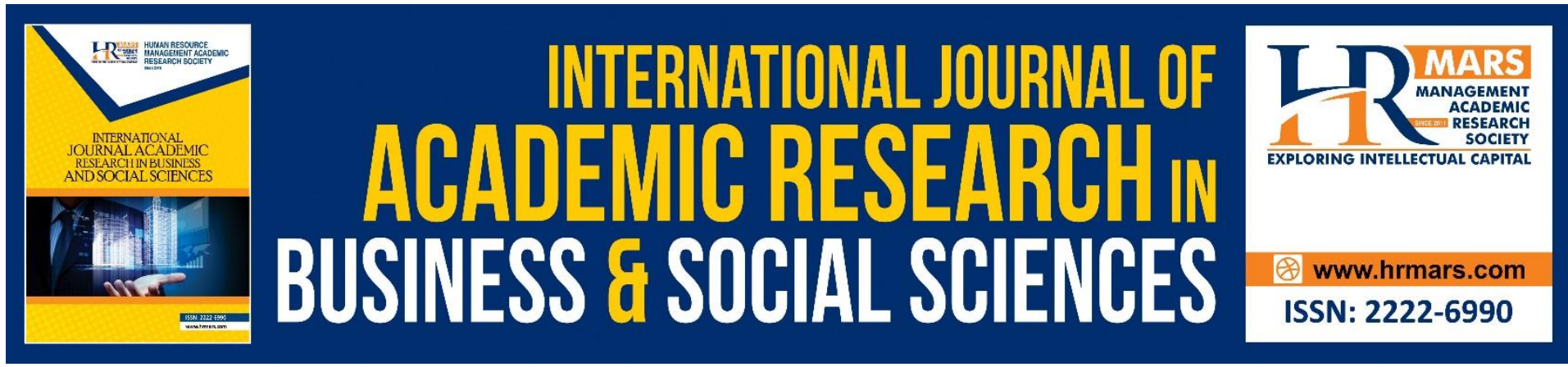

\title{
Fostering Innovation in Education Industry: The Mediating Role of Knowledge Transfer
}

\author{
Siti Nurellyza Suria Ab. Rahim¹, Nor Lelawati Jamaludin², Siti \\ Suriawati Isa ${ }^{3}$ \\ ${ }^{1}$ Faculty of Business and Management, Universiti Teknologi MARA, Shah Alam, Selangor, \\ Malaysia, ${ }^{2}$ Faculty of Business and Management, Universiti Teknologi MARA, Shah Alam, \\ Selangor, Malaysia, ${ }^{3}$ Faculty of Forestry, Universiti Putra Malaysia, Serdang, Selangor, \\ Malaysia
}

Corresponding Author Email: norlelawati0019@uitm.edu.my

\begin{abstract}
The education industry is debating how to grow profits in the face of strong competition and the current global economic crisis. Focusing on innovation, according to research, provides a new viewpoint on value generation and performance enhancement. Thus, the goal of this study was to assess how personnel in the education industry create innovation through absorptive capability, knowledge transfer, and psychological empowerment. The respondents are from Universiti Teknologi MARA, Shah Alam. The data was collected by using a questionnaire to the 383 administrative staff. The data was analyses using Statistical Package for the Social Sciences 25 (SPSS25). Results showed that: knowledge transfer mediate the relationship between (1) absorptive capacity and innovation capability And (2) psychological empowerment and innovation capability. The novelty of this research is the contribution of the present body of knowledge through the development of the adapted model of innovation capability concerning the education industry. This new knowledge should aid in better assessing the potential impact of knowledge transfer and psychological empowerment, laying the framework for future research into the relationship between absorptive capacity and innovation. The findings may also assist stakeholders and policymakers in developing a plan and taking action to improve organization's innovative capability.
\end{abstract}

Keywords: Absorptive Capacity, Psychological Empowerment, Knowledge Transfer, Innovation Capability, Education Industry.

\section{Introduction}

This study tries to investigate the relationship between absorptive capacity, knowledge transfer, psychological empowerment and innovation in education industries in the Malaysian context. To the best of this researcher's knowledge, this concern has been overlooked in the context of absorptive capacity-innovation literature in both Malaysia and other business contexts until now (Ashtiani, 2014; Zhao, Jiang, Peng, \& Hong, 2020; Wang, Wang \& Chang, 2019). 
In the current competitive business environment, innovation is regarded as a key element for organizational success (Tohidi \& Jabbari, 2012; Alrowwad, \& Abualoush, 2020). With regards to the above matter, literature has proved that to increase the competitive advantage in a global and growing market, the education industry needs to focus on innovation (Lo \& Tian, 2020). In addition, findings discussed in The National Graduate Employability Blueprint indicates that graduates who graduated from institutions that acquire exploration attributes, with imaginative and innovative capability will lead to higher changes of employability. Further, Kandampully, Bilgihan \& Zhang (2016); Bani-Melhem et al (2018) also concluded that innovation is one of the most important components to gain competitive advantage.

According to an analysis of major international scientific journals databases, limited study is reviewing previous research to identify the factors of innovation (Hjalager, 2010; Kallmuenzer \& Peters, 2018; Kandampully et al 2016; Law et al., 2014). The authors discovered shortcomings in the knowledge transfer and psychological processes that must be addressed in order to cater the requirements of employee's needs. Thus, a study in organizational innovation context must be configured with an eye on factors influencing and enhancing it to achieve more effective results in education institutions and to achieve competitive advantage.

However, before proceeding to examine more on factors influencing innovation capability, it is important to understand and see where we are right now. Based on the study by Balasubramaniam \& Ragavan (2019), it can be concluded that the implementation of innovation strategies is still one of the biggest hurdles in Malaysia.

In addition, several researchers, (Chen et al., 2017; Grisseman et al., 2013) stress that innovation will result in a positive influence on performance. In this vein, it is critical to identify major drivers of innovation, and top management in the education industry should be aware of these major drivers in order to execute such innovation initiatives. Although previous studies have discussed firms' innovation (i.e., Chesbrough, Lettl, \& Ritter, 2018; Manville et al., 2019; Saebi \& Foss, 2015; Torchia \& Calabrò, 2019), consensus on the key drivers of innovation is still inconclusive, (Saebi \& Foss, 2015). Innovation has been always driven by knowledge transfer processes, (Darroch \& McNaughton, 2003; Nonaka \& Takeuchi, 2007), absorptive capacity (Ye, Liu, \& Tan, 2021) and psychological empowerment (Shafait, Yuming, \& Sahibzada, 2021).

The interest in the successful knowledge transfer to achieve organisational goals, such as innovation, is expressed in the increasingly growing literature (see Hakim \& Hassan, 2011; Darroch \& McNaughton, 2003; Shahzad et al., 2020). The effective knowledge transfer process is often cited as an antecedent of innovation, (Ashtiani, 2014). In addition, a review of earlier studies investigating the relationship between knowledge transfer and innovation highlights important findings that knowledge transfer showed significant potential to enhance organizational innovation, (Lin, 2007; Rhodes et al., 2008; Hakim \& Hassan, 2011).

Furthermore, a major part of the economic growth of developed countries comes through innovation (Ghorbani et al., 2012). Innovation and knowledge transfer are now vital requirements in modern business and have attracted Malaysian scholars, (Bashir \& Farooq, 2019) and practitioners. Knowledge-based theory has, in the past, both attempted to explain knowledge sharing and innovation, (Ashtiani, 2014). However, studies conducted in each research stream, independent of the other, have disregarded the other theory's potential impact. In effect, one could say that the effect of absorptive capacity on innovation might be different in the knowledge transfer context (Zhao et al., 2020). 
With regards to the above, it has been proposed that absorptive capacity is one of the determinants of knowledge transfer, Gupta \& Govindarajan (2000); Lo \& Tian (2020) and innovation (Ye, Liu, \& Tan, 2021). In addition, according to, (Pateli \& Lioukas, 2019; (Nonaka \& Takeuchi, 2007); (Fujiwara, 2020), organizations innovation initiatives require knowledge, integrating it with current knowledge from diverse functional domains and turning it into a variety of innovative outputs.

Knowledge transfer and absorptive capacity are linked; improving absorptive capacity will likely improve knowledge transfer (Racz \& Borza, 2016). Effective knowledge transfer strategies must consider the absorptive capacity of the knowledge recipients, (Whitehead, Zacharia \& Prater, 2016). However, an educational institution's absorptive capacity has been mainly undeveloped, (Mariano \& Walter, 2015).

As a response, further research is required to investigate efficient absorptive capacity solutions that can boost receivers' knowledge while also streamlining existing innovation approaches, (Ferreira \& Carayannis, 2019; Yuwono, 2021). Following that, Cheng \& Eric (2020) and Santoro, Bresciani, \& Papa (2020) pointed out that the impact of knowledge transfer on innovation can vary depending on absorptive capacity. This research is critical since it has both theoretical and practical ramifications.

Theoretically, this study contributes to the body of knowledge because it enriches the empirical application of absorptive capacity and knowledge transfer theory (Pangarso, Astuti, Raharjo, \& Afrianty, 2020). The practical implications are motivated by practical problems, especially in the context of higher education (Pangarso, Astuti, Raharjo, \& Afrianty, 2020). Human capital techniques are also important to achieve innovation in organisations, (Alshekaili \& Boerhannoeddin, 2011; Pizarro et al., 2009). Nikpour (2018), suggested that human capital approaches can be improved through psychological empowerment. In this regard, research suggests that psychological empowerment at the individual level has become increasingly important in terms of supporting the provision, sharing, and distribution of information and knowledge in organisations, as well as innovation (Amichai-Hamburger \& Samuel-Azran, 2008; Wang et al., 2019). By examining the gap between knowledge and human capital approaches in influencing innovation, this study contributes to the expansion of Malaysia's education industry potential.

The current study recognizes the value of identifying the linkages between knowledge transfers and psychological empowerment that influence innovation based on the literature. As a logical consequence, the study seeks to address a gap in the literature by merging information transfer and psychological empowerment to optimize educational innovation. To the best of the authors knowledge, there has been no previous work considering this relationship in the education industry, particularly in the Malaysian context.

In general, it can be concluded that among all, firms' innovation relies on factors such as absorptive capacity (Ye et al., 2021), knowledge transfer (Chesbrough, 2011), and psychological empowerment (Wang et al., 2019). In addition, previous research by (Xie, Zou, \& Qi, 2018; Wang et al., 2019; Fayyaz, Chaudry, \& Fiaz, 2021; Cheng \& Eric, 2020; Steed \& Gair, 2020 and Müller, Buliga, \& Voight, 2018) also supported suggestions on further study on the impact of absorptive capacity, knowledge transfer, psychological empowerment on innovation. These prior studies, however, have limitations because they were conducted in a confined context and country, necessitating more research in different industrial sectors and/or countries. Thus, the study in the area where it is plausible such as Malaysia is justified. However, taking into account various contextual circumstances that may have an impact on the expected outcomes could provide an additional explanation. In this view, the researcher 
found that little research attention has been devoted to examining how psychological empowerment via knowledge transfer enhances innovation (Wang, Wang, \& Chang, 2019). Thus, the putative mediating role of knowledge transfer was investigated in this study in response to recommendations for establishing integrative models that clarify the impacts of absorptive capacity and psychological empowerment on innovation development, (Steed \& Gair, 2020; Wang, Wang, \& Chang, 2019; Zhao et al., 2020).

The authors believes that this effort could bring more to the table by not only devouring deeper but also taking a new perspective which are often overlooked by researchers although their takes could be a turning point for the industry. This is especially relevant given that this research is being conducted in the education sector, which is a knowledge-intensive environment with high levels of social interaction.

Thus, the investigations on the mediating relationship of knowledge transfer to the relationship between absorptive capacity, psychological empowerment and innovation which is still at scarce are justified. This new knowledge should aid in better assessing the potential impact of knowledge transfer and psychological empowerment, laying the framework for future research into the relationship between absorptive capacity and innovation. Thus, further study on the mediating effect is necessary.

In summary, the statement problem highlighted the importance of understanding the relationship between absorptive capacity - knowledge transfer -psychological empowermentinnovations. This study provides a comprehensive look at how these variables interact and influence one another. By linking knowledge transfer and psychological empowerment perspective in the absorptive capacity - innovation domain, it could add to knowledge transfer research. The findings may also assist stakeholders and policymakers in developing a plan and taking action to enhance innovation.

\section{Literature Review}

A major part of the economic growth of developed countries comes through innovation (Ghorbani, Mofaredi, \& Bashiriyan, 2012); (Asunka et al., 2021) innovation has been constantly studied to serve customers better (Truong, Dang-Pham, McClelland, \& Nkhoma, 2020). The review of literature on the innovation framework developed by (Wang, Wang, \& Chang , 2019; Ashtiani, 2014; Szulanski \& Capetta, 2003; Nahapiet \& Ghoshal, 1998) and other scholars appear to identify elements that promote innovation culture. However, there is no definitive agreement on the major drivers of innovation in the education industry, (Lo \& Tian, 2020). As a result, the goal of this research is to understand more about the factors that contribute to educational innovation. Literature has proved that to increase the competitive advantage in a global and growing market, industry needs to focus on innovation (Kandampully, Bilgihan, \& Zhang, 2016).

Moving ahead, it has been suggested that the receiving unit's absorptive ability is the most important factor of internal knowledge transfer, (Gupta \& Govindarajan, 2000) and it is known that innovation relies heavily on the creation of new knowledge (Nonaka \& Takeuchi, 2007); (Fujiwara, 2020). Knowledge transfer and absorptive capacity are linked; improving absorptive capacity will likely improve knowledge transfer (Racz \& Borza, 2016). Effective knowledge transfer strategies must consider the absorptive capacity of the knowledge recipients (Whitehead, Zacharia, \& Prater, 2016).

Absorptive capacity is the ability through which an organization acquires knowledge (Liao, Fei, $\&$ Chen, 2007). However, the absorptive capacity of an education institution has been largely 
underdeveloped (Mariano \& Walter, 2015). Further research needs to be conducted to examine effective knowledge transfer practices that can enhance the absorption capacity of knowledge recipients and to streamline existing innovation models (Ferreira \& Carayannis, 2019).

Furthermore, individual psychological empowerment has become increasingly important in terms of supporting the provision, sharing, and distribution of information, power, and expertise in businesses, as well as innovation (Wang, Wang, \& Chang, 2019). In general, it can be inferred that a firm's ability to innovate is driven by factors such as knowledge transfer (Chesbrough, 2011), absorptive capacity (Ye, Liu, \& Tan, 2021) and psychological empowerment (Wang, Wang, \& Chang, 2019).

Furthermore, research has revealed that an organization's ability to innovate is strongly influenced by the level of knowledge sharing among its employees (Noor \& Egbu, 2010). In addition, as innovation relies heavily on the creation of new knowledge (Nonaka \& Takeuchi, 2007; Fujiwara, 2020), to acquire, produce, share, and apply information quickly and efficiently, businesses must invest in knowledge transfer approaches (Cavusgil, Calantone, \& Zhao, 2003).

As pointed out in the literature, it is acknowledged that innovations are now vital requirements in modern business to remain competitive, (Ashtiani, 2014). Following this, (Zhao, Jiang, Peng, \& Hong, 2020; Lo \& Tian, 2020; Santoro, Bresciani, \& Papa, 2020 and Wang, Wang, \& Chang, 2019) mentioned that the effect of absorptive capacity and psychological empowerment on the innovation may be different in the sense of knowledge transfer. The researchers asserted that innovation increased with the impact of absorptive capacity and psychological empowerment especially when higher knowledge transfer was evident (Santoro, Bresciani, \& Papa, 2020).

It is also confirmed that knowledge transfer is influence by absorptive capacity of the knowledge recipients (Whitehead, Zacharia, \& Prater, 2016) and psychological empowerment (Wang, Wang, \& Chang, 2019). Knowledge transfer also plays a remarkable role in influencing innovation capability (Müller, Buliga, \& Voight, 2018). In addition, Cheng \& Eric, (2020) and Steed \& Gair, (2020) suggested that absorptive capacity influence innovation.

Further, Zhao et al (2020); Lo \& Tian (2020) highlights the possible mediating role of knowledge transfer can alter the impact of the organizational innovation on the extent of absorptive capacity and psychological empowerment (Wang et al., 2019). This points out that absorptive capacity and psychological empowerment has a significant role in managing knowledge transfer, and that this requires more attention from organizational management in their practice. This rationale clearly emphasizes the potential influence of knowledge transfer for nurturing absorptive capacity, psychological empowerment towards innovation. Thus, the investigations on the mediating relationship are justified. Nevertheless, key to increasing innovation capability lies in resolving the issues relating to knowledge transfer, absorptive capacity, and psychological empowerment which is discussed below.

\section{Knowledge Transfer Mediates the Relationship between Psychological Empowerment and Innovation}

The process of knowledge transfer consists of "supply" and "demand" activities towards new knowledge. That is, some people require additional knowledge (for example, to solve specific work challenges), whereas others are willing to share what they know. Knowledge transfer is crucial because it enables people to work on existing knowledge within and outside the 
organization, thus enhancing their capacity to come up with creative solutions and enabling their organizations to develop new platforms for the development of new products and services to the market (Nonaka \& Takeuchi, 2007; Wang \& Noe, 2010).

Conversely, when knowledge is not shared, it hinders the capacity to exploit experience and expertise (Hansen, 2002). Troy et al (2001) found that communication and knowledge transfer and availability of market information were interacted in predicting new product ideas and innovation. In addition, previous studies also concluded that psychological empowerment plays an important role in nourishing employees' innovative work behavior (Marane, 2012; Seibert, Wang, \& Courtright, 2011; Singh, Sharma, \& Sarkar, 2012). Empowered employees will exhibit more innovative behavior and achieve better task performance (Asfar, Cheema, \& Saeed, 2017).

Individual psychological empowerment is regarded to be one of the factors that contribute to increased interpersonal trust and a higher likelihood of repeating the empowered act, (Ferriani, Cattani, \& Baden-Fuller, 2009). However, while a number of studies have investigated the effect of empowering employees' knowledge sharing and innovation, (i.e., Wang, Wang, \& Chang , 2019) little research attention has been devoted to examining how knowledge transfer behavior via psychological empowerment related to innovation. Further, Wang, Wang \& Chang (2019) confirmed that knowledge transfer mediates the relationship between psychological empowerment and innovation.

\section{Knowledge Transfer Mediates the Relationship between Absorptive Capacity and Innovation}

Previous research has examined the concept of knowledge absorptive capacity in the context of different fields of study, including organization theory, strategic management, and economics (Lewin, Massini, \& Peeters, 2011). A firm's absorptive capacity is also important to their innovation activities (Leal-Rodríguez, Ariza-Montes, Roldán, \& Leal-Millán, 2014). Moreover, absorptive capacity plays a leading role in determining the magnitude and range of knowledge flows (Hurmelinna-Laukkanen, Olander, Blomqvist, \& Panfilii, 2012). Therefore, knowledge absorptive capacity, as a capability that continuously acquires, digests, and utilizes external knowledge, has become an important process necessary for a firm to identify market opportunities and use new knowledge to realize innovation.

In addition, (Zhao, Jiang, Peng, \& Hong, 2020) and (Lo \& Tian, 2020) highlights the possible mediating role of absorptive capacity can alter the impact of the organizational innovation on the extent of knowledge transfer. This emphasises the importance of absorptive capacity in managing knowledge transfer, which necessitates more attention from organisational structure. This rationale clearly emphasizes the potential influence of knowledge transfer for nurturing absorptive capacity towards innovation.

H1: Knowledge transfer mediates the relationship between absorptive capacity and innovation capability in the education industry in Malaysia

$\mathrm{H} 2$ : Knowledge transfer mediates the relationship between psychological empowerment and innovation capability in the education industry in Malaysia

\section{Method}

\section{Sample and Procedure}

The sample size is one aspect of study design that researchers need to remember when they prepare their research, according to Burmeister, Elizabeth, Aitken, and Leanne (2012). 
Reasons for correctly measuring the necessary sample size include producing both clinically and statistically meaningful outcomes and ensuring the effective and ethical usage of study resources. Since the population of UiTM administrative staff in Shah Alam is 2,709 employees, according to Krejcie and Morgan, (1970) minimum sample size needed is 393 . The responses were obtained from a list of administrative staff in UiTM Shah Alam. The data were analyzed using the Statistical Package for Social Science 25 (SPSS25). The assumption test was performed to decide which responses were important based on degrees of consensus to the different goals.

\section{Measurement of the Variables}

The entire variables were measured by using a five-point Likert scale format. Studies have generally shown that five-to seven-point scales of measurement can improve its reliability and validity (Mitchell, Van Den Land, and Levy, 2018). Thus, each of the continuous variables is measured by a five-point Likert Scale.

\section{Results and Discussion}

Demographic

The descriptive analyses of respondents' demographic data where are also carried out by the researcher using SPSS. Gender, age, marital status, educational level, and employment base are all factors to consider. The analyses as in the Table 1 below.

Table 1: Demographic

\begin{tabular}{llll}
\hline Demographic Variable & Categories & Frequencies & Percentage (\%) \\
\hline Gender & Male & 176 & 44.8 \\
Age & Female & 217 & 55.2 \\
& Less than 30 years & 87 & 22.1 \\
& $30-40$ years & 204 & 51.9 \\
Marital Status & $40-50$ years & 64 & 16.3 \\
& 50 years and above & 38 & 9.7 \\
Education Level & Single & 108 & 27.5 \\
& Married & 283 & 72.0 \\
& Others & 2 & 0.5 \\
& PMR & 6 & 1.5 \\
& SPM & 104 & 26.5 \\
& STPM & 14 & 3.6 \\
& Diploma & 89 & 22.6 \\
Employment Basis & Degree & 111 & 28.2 \\
& Masters & 65 & 16.5 \\
& PHD & 4 & 1.0 \\
& Full - time & 351 & 89.3 \\
& Part - time & 11 & 2.8 \\
& Contract & 10 & 2.5 \\
& Internship & 21 & 5.3 \\
\hline
\end{tabular}




\section{Descriptive Statistic}

Researcher used two modes to measure variability which is Mean and Standard Deviation (SD). For the independent and mediating variables of absorptive capacity, knowledge transfer, and psychological empowerment used. Individual/ respondent generally choose from five alternative which is range from 1 to 5, with 1 strongly disagree, 2 disagree, 3 indicating neutrality, 4 agree, and 5 strongly agree. Same goes to dependent variables innovation capability also used Likert scale as 1 to 5 to measure their range. Results in Table 2 indicates that the mean score for the dependent variable which is Innovation is 3.658 indicating a high mean score. While independent and moderating variables which are absorptive capacity, knowledge transfer and psychological empowerment also indicating a high mean score of 3.438, 4.183 and 4.022 respectively. Further, standard deviation of all value can also be considered as acceptable.

Table 2: Descriptive

\begin{tabular}{lll}
\hline Variables & Mean (M) & $\begin{array}{l}\text { Standard } \\
\text { Deviation (SD) }\end{array}$ \\
\hline Absorptive Capacity & 3.438 & 0.604 \\
Knowledge Transfer & 4.183 & 0.501 \\
Psychological Empowerment & 4.022 & 0.742 \\
Innovation & 3.658 & 0.683 \\
\hline
\end{tabular}

\section{Hypotheses Testing}

\section{PROCESS macro-Hayes for $\mathrm{H} 1$}

The mediation analysis, Andrew Hayes's PROCESS macro, was used to examine the effect of absorptive capacity (X-variables) on the innovation capability (Y-variable) mediates by knowledge transfer (W-variable) to analyse the first hypothesis of this study. The results of the analysis are explained further below in details. The results in Table 3 shows that $F(3,92)$ $=58.771, p<.001, R^{2}=.657$. This meant that $65.7 \%$ of the variance was due to knowledge transfer.

Table 3: Model Summary using Andres Hayes's PROCESS Macro

\begin{tabular}{llllllll}
\hline & $R$ & R & MSE & $F$ & $d f l$ & $d f l 2$ & $p$ \\
\hline 1 & .8106 & .657 & .555 & 58.771 & 3.000 & 92.000 & 0.000 \\
\hline
\end{tabular}

Table 4: Result of PROCESS macro-Hayes for $\mathrm{H} 1$

\begin{tabular}{|l|l|l|l|l|l|l|}
\hline $\begin{array}{l}\text { Variable / } \\
\text { Effect }\end{array}$ & $\mathbf{b}$ & Se & $\mathbf{t}$ & $\mathbf{p}$ & \multicolumn{2}{|l|}{ 95\% Confidence Interval } \\
\hline $\mathrm{AC} \longrightarrow \mathrm{I}$ & .0426 & .2190 & .1946 & $>.001$ & .477 & .391 \\
\hline $\mathrm{AC} \longrightarrow \mathrm{KT}$ & .0529 & .0547 & .9669 & $>.05$ & .056 & .161 \\
\hline $\mathrm{AC} \rightarrow \mathrm{KT} \rightarrow \mathrm{I}$ & .0048 & .0234 & .2740 & .000 & .042 & .051 \\
\hline
\end{tabular}

*AC: Absorptive Capacity; KT: Knowledge Transfer; I: Innovation 
Table 5: Effects

\begin{tabular}{|l|c|c|c|c|c|c|}
\hline Direct & .0529 & .0547 & .9669 & $<.05$ & .0555 & .1613 \\
\hline Indirect & .0002 & .0047 & & & .0128 & .0077 \\
\hline Total & .0527 & .0545 & .9674 & .00 & .0552 & .1606 \\
\hline
\end{tabular}

Based on the Table 4, first, the results of the regression analysis show that independent variable, absorptive capacity was not a significant predictor of innovation capability $(b=$ $.0426, t=.1946, p>.001$ ). Next, while controlling for knowledge transfer (mediator), the results of the second regression analysis also show that the independent variable, absorptive capacity was not significant predictor of knowledge transfer $(b=.0529, t=.9669, p>.05)$. However, when mediator was included, the relationship between absorptive capacity and innovation capability is significant $(b=.0048, t=.2740, p=.000)$.

Moreover, in Table 5, there was also statistically insignificant direct effect between absorptive capacity and innovation capability $(b=.0529, t=.0547, p<.05)$. However, the results of the indirect effect based on 5000 bootstrap samples show a significant indirect relationship between absorptive capacity and innovation capability mediate by knowledge transfer $(a * b=$ .0002 , Bootstrap $=.0128$ and .0077$)$. Thus, it can be concluded that H1: Knowledge transfer mediates the relationship between absorptive capacity and innovation capability in the education industry in Malaysia is accepted.

\section{PROCESS macro-Hayes for $\mathrm{H} 2$}

The mediation analysis, Andrew Hayes's PROCESS macro, was used to examine the effect of psychological empowerment (X-variables) on innovation capability ( $Y$-variable) mediates by knowledge transfer (W-variable) to analyze the second hypothesis of this study. The results of the analysis are explained further below in details. The results in Table 6 shows that $F(3$, $92)=56.66, p<.001, R^{2}=.757$. This meant that $75.7 \%$ of the variance was due to knowledge transfer.

Table 6: Model Summary using Andres Hayes's PROCESS Macro

\begin{tabular}{llllllll}
\hline & $\mathrm{R}$ & $\mathrm{R}$ Square & $\mathrm{MSE}$ & $\mathrm{F}$ & $\mathrm{dfl}$ & $\mathrm{dfl} 2$ & $\mathrm{p}$ \\
\hline 1 & .800 & .757 & .515 & 56.661 & 3.000 & 92.000 & 0.000 \\
\hline
\end{tabular}


Table 7: Result of PROCESS macro-Hayes for $\mathrm{H} 1$

\begin{tabular}{|l|l|l|l|l|l|l|}
\hline $\begin{array}{l}\text { Variable / } \\
\text { Effect }\end{array}$ & $\mathbf{b}$ & Se & $\mathbf{t}$ & $\mathbf{p}$ & \multicolumn{2}{|l|}{ 95\% Confidence Interval } \\
\hline $\mathrm{PE} \longrightarrow \mathrm{I}$ & .0413 & .2091 & .1845 & $>.001$ & .4667 & .3712 \\
\hline $\mathrm{PE} \longrightarrow \mathrm{KT}$ & .0428 & .0546 & .9615 & $>.05$ & .0565 & .1512 \\
\hline $\mathrm{PE} \rightarrow \mathrm{KT} \rightarrow \mathrm{I}$ & .0075 & .0231 & .2787 & .000 & .0413 & .0611 \\
\hline
\end{tabular}

*PE: Psychological empowerment; KT: Knowledge Transfer; I: Innovation

Table 8: Effects

\begin{tabular}{|l|c|c|c|c|c|c|}
\hline Direct & .0519 & .0557 & .9719 & $>.05$ & .0555 & .1613 \\
\hline Indirect & .0003 & .0047 & & & .0127 & .0078 \\
\hline Total & .0527 & .0545 & .9674 & .000 & .0552 & .1606 \\
\hline
\end{tabular}

Based on the Table 7, first, the results of the regression analysis show that independent variable, psychological empowerment was not a significant predictor of innovation capability $(b=.0413, t=.1845, p>.001)$. Next, while controlling for knowledge transfer (mediator), the results of the second regression analysis also show that the independent variable, psychological empowerment was not significant predictor of knowledge transfer $(b=.0428, t$ $=.9615, \mathrm{p}>.05)$. However, when mediator was included, the relationship between psychological empowerment and innovation capability is significant $(b=.0075, t=.2787, p=$ $.000)$.

Moreover, results in Table 8 shows that there was also statistically insignificant direct effect between absorptive capacity and innovation capability $(b=.0519, t=.0557, p>.05)$. However, the results of the indirect effect based on 5000 bootstrap samples show a significant indirect relationship between absorptive capacity and innovation capability mediate by knowledge transfer $(\mathrm{a} * \mathrm{~b}=.0003$, Bootstrap $\mathrm{Cl} 95=.0127$ and .0078$)$. Thus, it can be concluded that $\mathrm{H} 2$ : Knowledge transfer mediates the relationship between psychological empowerment and innovation capability in the education industry in Malaysia is accepted.

\section{Conclusions}

As hypothesized, knowledge transfer mediates relationship between both absorptive capacity, psychological empowerment and innovation capability in Malaysia's education sector. Hence, findings from this research are at par with (Cheng \& Eric, 2020; Santoro, Bresciani \& Papa, 2020; Wang, Wang \& Chang, 2019). Innovation relies heavily on absorptive capacity and psychological empowerment which upon intersection of knowledge transfer will further improves the analogy. Knowledge transfer among employees is crucial part in integrating, exchanging and communicating ideas solutions to meet optimal results as the increase in connectivity via interaction will promise greater effect of absorptive capacity and psychological empowerment have direct impact on innovation. It is highlighted in the research, knowledge transfer mediates the relationship between absorptive capacity, psychological empowerment and innovation in education industry in Malaysia.

This study provides empirical evidence that knowledge transfer mediates the relationship between psychological empowerment on innovation capability. To enhance innovation 
capabilities, this study introduces and develops an integrative model that integrates knowledge-based and social empowerment concepts. Based on researcher findings, the empowering employees to make decision and weighing their point of view instil another level of psychological empowerment incorporated with smooth flow of absorptive capacity predicts better innovation quality. This finding is important as it demonstrates the ground relationship of innovation for future researchers both in education and industrial fields. Representation of the mediating role between variables have set new spectrum of perspectives to alleviates innovation in education department. This research has set new line relationship which often have been overlooked previously. Finally, assertion of the findings suggests both education and industrial industry have new breaking point to consider from now onwards.

\section{Implications}

This study provides a number of academic and practical contributions. Knowledge Transfer as a mediating variable provides a fresh findings and it made a significant contribution to the research on innovative capability. Both innovation and education institutions should realize and ensure employees are connected with proper guidance through optimal level of communication resulting the best of knowledge transfer among them. These aspects are important in setting the healthy environment for the best outcome possible which impacts innovation heavily at the end results.

Second, this study also provides guidelines for practitioners, especially in education institutions. Management must empower employees as it motivates one's drive and motivation psychologically. To empower the employees, management must pay more attention to employees' knowledge sharing and nurture the realization of their ideas with open mind to appreciate all ideas from each individual's. Moreover, organizations especially education institutions need a good knowledge sharing culture in the work environment as it lead to better understanding of company's vision which brings optimal quality to innovation.

\section{Limitations and Suggestions for Future Research}

This study contains several limitations and can be further developed in the future. First, one of the limitations of the cross-section method is that it cannot prove a causal relationship. Therefore, a longitudinal design is needed, although this will not completely resolve the difficulty of proving a cause-and-effect relationship (Carmeli \& Spreitzer, 2009). Second, this study conducted in the Malaysian context. The results may be different for employees working in various cultural, economic, and environmental conditions.

This study gives a novelty for further research to find out the absorptive capacity, psychological empowerment and knowledge transfer mechanism that is appropriate for other organizations. Education sectors in Malaysia need to put more focus on psychological empowerment of employees' nourishing them with morale support and boosting up motivation upon completing task which will have direct impact on innovation. Education industry needs to highlight the importance of absorptive capacity among employees by providing systematic flow of information in the institutions. Lastly, education industry must take into consideration power of knowledge transfer as part of the equation to come up with the best innovation which have been disregarded on previously. 


\section{Acknowledgement}

We would like to extend our thanks to the editors and reviewers of the journal, who helped tremendously in improving the quality of this manuscript. Thanks also to the administrative staffs at UiTM Shah Alam for facilitating the data collection process for this study.

\section{References}

Alshekaili, S., \& Boerhannoeddin, A. (2011). Human Capital Approach Towards Enhancing Innovation In Omani Industrial Firms: The Role of Knowledge Management. Progress in Business Innovation \& Technology Management 1, 23-33.

Alrowwad, A. A., \& Abualoush, S. H. (2020). Innovation and intellectual capital as intermediary variables among transformational leadership, transactional leadership, and organizational performance. Journal of Management Development.

Asfar, B., Cheema, S., \& Saeed, B. (2017). Do Nurses Display Innovative Work Behavior When Their Values Match with Hospitals' Values. European Journal of Innovation Management, 1-17.

Ashtiani, A. V. (2014). A study on knowledge sharing practices and innovation capability: A social capital perspective (Doctoral dissertation, University Malaya).

Asunka, B. A., Ma, Z., Li, M., Amowine, N., Anaba, O. A., Xie, H., \& Hu, W. (2021). Analysis of the causal effects of imports and foreign direct investments on indigenous innovation in developing countries. International Journal of Emerging Markets.

Balasubramanian, K., \& Ragavan, N. A. (2019). What are the key challenges faced by the Malaysian hospitality and tourism industry in the context of industrial revolution 4.0?. Worldwide Hospitality and Tourism Themes.

Bani-Melhem, S., Zeffane, R., \& Albaity, M. (2018). Determinants of employees' innovative behavior. International Journal of Contemporary Hospitality Management.

Barachini, F. (2009). Cultural and Social Issues for Knowledge Sharing. Journal of Knowledge Management, 1-15.

Bashir, M., \& Farooq, R. (2019). The Synergetic Effect of Knowledge Management and Business Model Innovation on Firm Competence. International Journal of Innovation Science, 362-378.

Cavusgil, S., Calantone, R., \& Zhao, Y. (2003). Tacit knowledge transfer and firm innovation capability. Journal of Business \& Industrial Marketing, 18(1), 6-21.

Chen, J. S., Kerr, D., Chou, C. Y., \& Ang, C. (2017). Business co-creation for service innovation in the hospitality and tourism industry. International Journal of Contemporary Hospitality Management.

Cheng, E. C. K. (2020). "Knowledge transfer strategies and practices for higher education institutions." VINE Journal of Information and Knowledge Management Systems.

Chesbrough, H., Lettl, C., \& Ritter, T. (2018). Value creation and value capture in open innovation. Journal of Product Innovation Management, 35(6), 930-938.

Darroch, J., \& McNaughton, R. (2003). Beyond market orientation: Knowledge management and the innovativeness of New Zealand firms. European Journal of Marketing, 37(3/4), 572-93.

Fayyaz, A., Chaudry, B., \& Fiaz, M. (2021). Upholding Knowledge Sharing for Organization Innovation Efficiency in Pakistan. Journal of Open Innovation, 7,4, 1-17.

Ferreira, J., \& Carayannis, E. (2019). University-Industry Knowledge Transfer - Unpacking the 'black-box' : an Introduction. Knowledge Management Research and Practice, Vol 17, No 4, 353-357. 
Ferriani, S., Cattani, G., \& Baden-Fuller, C. (2009). The Relational Antecedents of ProjectEntrepreneurship: Network Centrality,Team Composition and Project Performance. Research Policy 38, 1545-1558.

Fujiwara, A. (2020, March). Who is Generating New Innovations?: An Analysis of Blockchain Engineers. In 2020 6th International Conference on Information Management (ICIM) (pp. 289-294). IEEE.

Ghorbani, M., Mofaredi, B. \& Bashiriyan, S. (2012). Study of the relationship between intellectual capital management and organizational innovation in the banks. African Journal of Business Management, 6(15), 5208-17.

Gupta, A., \& Govindarajan, V. (2000). Knowledge Flows within MNCs. Strategic Mangement Journal,21,4, 473-496.

Grissemann, U., Plank, A., \& Brunner-Sperdin, A. (2013). Enhancing business performance of hotels: The role of innovation and customer orientation. International Journal of Hospitality Management, 33, 347-356.

Hakim, A., L.A.Y, \& Hassan, S. (2011). The Role of Middle Managers in Knowledge Management Implementation for Innovation Enhancement. Journal of Innovation, Management and Technology (IJIMT), 2 (1), 86-94.

Hansen, J. (2002). A Brighter Future. Climatic Change, Vol 52, No 4, 435-440.

Heick, T. (2021).12 Barriers To Innovation In Education. Retrieved from https://www.teachthought.com/the-future-of-learning/12-barriers-innovationeducation/

Hjalager, A. M. (2010). A review of innovation research in tourism. Tourism Management, 31(01), 01-12.

Kallmuenzer, A., \& Peters, M. (2018). Innovativeness and control mechanisms in tourism and hospitality family firms: A comparative study. International Journal of Hospitality Management, 70,66-74.

Kandampully, J., Bilgihan, A., \& Zhang, T. C. (2016). Developing a people-technology hybrids model to unleash innovation and creativity: The new hospitality frontier. Journal of Hospitality and Tourism Management, 29, 154-164.

Law, R., Buhalis, D., \& Cobanoglu, C. (2014). Progress on information and communication technologies in hospitality and tourism. International Journal of Contemporary Hospitality Management.

Liao, S., Fei, W. C. \& Chen, C. C. (2007b). Knowledge sharing, absorptive capacity, and nnovation capability: an empirical study of Taiwan's knowledge-intensive industries. Journal of Information Science, 33(3), 340-59.

Lin, C.-Y. (2007). Factors Affecting Innovation in Logistics Technologies for Logistic Service Providers in China. Journal of Technology Management in China, Vol 2, No 1, 22-39.

Lo, M. F., \& Tian, F. (2020). Enhancing competitive advantage in Hong Kong higher education: Linking knowledge sharing, absorptive capacity and innovation capability. Higher Education Quarterly, 74(4), 426-441.

Lu, L., Leung, K., \& Koch, P. (2006). Managerial Knowledge Sharing: The Role of Individual, Interpersonal, and Organizational Factors. Management and Organization Review, 2, $15-41$.

Manville, G., Karakas, F., Polkinghorne, M., \& Petford, N. (2019). Supporting open innovation with the use of a balanced scorecard approach: a study on deep smarts and effective knowledge transfer to SMEs. Production Planning \& Control, 30(10-12), 842-853.

Marane, B. (2012). The Mediating Role of Trust in Organization on the Influence of 
Psychological Empowerment on Innovation Behavior. European Journal of Social Sciences, 33 (1), 39-51.

Mariano, S., \& Walter, C. (2015). The Construct of Absorptive Capacity in Knowledge Management and Intellectual Capital Research: Content and Text Analyses. Journal Knowledge and Management, Volume 19, 372-400.

Noor, M. F., \& Egbu, C. (2010). The Impact of Organisational Size on the Implementation of Knowledge Sharing Practices in Quantity Surveying Firms in Malaysia. Retrieved from University of Salford Manchester: http://usir.salford.ac.uk/id/eprint/12826/

Müller, J., Buliga, O., \& Voight, K.-I. (2018). Fortune favors the prepared: How SMEs approach business model innovations in Industry 4.0. Technological Forecasting and Social Change, Volume 132, 2-17.

Nahapiet, J., \& Ghoshal, S. (1998). Social capital, intellectual capital and the organizational advan-tage. Academy of Management Review, 23(2), 242-266.

Nonaka, I., \& Takeuchi, H. (2007). The knowledge-creating company. Harvard business review, 85(7/8), 162.

Nonaka \& Takeuchi. (1995). The Knowledge-creating Company: How Japanese Companies Create the Dynamics of Innovation. Oxford University Press, 1995 - Business \& Economics.

Nikpour, A. (2018). Psychological Empowerment and Organizational Innovation: Mediating Role of Job Satisfaction and Organizational Commitment . International Journal of Organizational Leadership, 7,106-119.

Pangarso, A., Astuti, E. S., Raharjo, K., \& Afrianty, T. W. (2020). Data of innovation ambidexterity as a mediator in the absorptive capacity impact on sustainable competitive advantage. Data in Brief, 105200.

https://doi.org/10.1016/j.dib.2020.105200

Pateli, A., \& Lioukas, S. (2019). How functional involvement affects the transformation of external knowledge into innovation outcomes. R\&D Management, 49(2), 224-238

Pizarro, I., Real, J., \& Rosa, M. (2009). The Role of Entrepreneurial Culture and Human Capital in Innovation.

Racz, B.-G., \& Borza, A. (2016). Increasing Absorptive Capacity to Improve Internal and External Knowledge Transfer Multinational Companies: A Multiple Case Study Approach. Management and Economics Review, Volume 1, Issue 2, 120-137.

Rhodes, J., Hung, R., Lok, P., Lien, \& Wu, C. (2008). Factors Influencing Organizational Knowledge Transfer: Implication for Corporate Performance. Journal of Knowledge Management, Vol 12, No 3, 84-100.

Saebi, T., \& Foss, N. J. (2015). Business models for open innovation: Matching heterogeneous open innovation strategies with business model dimensions. European Management Journal, 33(3), 201-213.

Santoro, G., Bresciani, S., \& Papa, A. (2020). Collaborative modes with cultural and creative industries and innovation performance: the moderating role of heterogeneous sources of knowledge and absorptive capacity. Technovation, 92, 102040.

Seibert, S., Wang, G., \& Courtright, S. (2011). Antecedents and Consequences of Psychological and Team Empowerment in Organizations: A Meta-Analytic Review. Journal of Applied Psychology, 96, 981-1003.

Shafait, Z., Yuming, Z., \& Sahibzada, U. (2021). Emotional Intelligence and Conflict Management: An Execution of Organizational Learning, Psychological Empowerment and Innovative Work Behaviour in Chinese Higher Education. Middle East Journal of 
Management, 8(1), 1-22.

Shahzad, M., Qu, Y., Zafar, A. U., Rehman, S. U., \& Islam, T. (2020). Exploring the influence of knowledge management process on corporate sustainable performance through green innovation. Journal of Knowledge Management.

Singh, B., Sharma, H., \& Sarkar, B. (2012). Optimization of Extraction of Antioxidants from Wheat Bran (Triticum spp.) Using Response Surface Methodology. Journal of Food Science and Technology, 49, 294-308.

Srivastava, A., Bartol, K., \& Locke, E. (2006). Empowering leadership in management teams: effects on knowledge sharing, efficacy, and performance. Acad Management Journal, 49, 1239-1251.

Steed, J. T., \& Gair, A. (2020). Enhancing 21st Century Interdisciplinary Design Skills within Higher Education through Knowledge Transfer Partnerships. In DS 104: Proceedings of the 22nd International Conference on Engineering and Product Design Education (E\&PDE 2020), VIA Design, VIA University in Herning, Denmark. 10th-11th September 2020.

Sun, Y., Liu, J., \& Ding, Y. (2021). Analysis of the relationship between open innovation, knowledge management capability and dual innovation. Technology Analysis \& Strategic Management, 32(1), 15-28.

Szulanski, G., \& Cappetta, R. (2003). Stickiness: Conceptualizing, measuring, and predicting difficulties in the transfer of knowledge within organizations. International Journal of Contemporary Hospitality Management, 30(03), 1978-1995.

Tohidi, H., \& Jabbari, M. M. (2012). Innovation as a success key for organizations. Procedia Technology, 1, 560-564.

Torchia, M., \& Calabrò, A. (2019). Open innovation in SMEs: A systematic literature review. Journal of Enterprising Culture, 27(02), 201-228.

Thomas, K., \& Velthouse, B. (1990). Cognitive Elements of Empowerment: An "Interpretive" Model of Intrinsic Task Motivation. Academy of Management Review, 15, 666-681.

Troy, L., Szymanski, D., \& Varadarajan, P. (2001). Generating New Product Ideas: An Initial Investigation of the Role of Market Information and Organizational Characteristics. Journal of the Academy of Marketing Science, Volume 29, Issue 1, 89.

Truong, N., Dang-Pham, D., McClelland, R., \& Nkhoma, M. (2020). Exploring the Impact of Innovativeness of Hospitality Service Operation on Customer Satisfaction. Operations and Supply Chain Management: An International Journal, 13(3), 307-319.

Wang, S., \& Noe, R. (2010). Knowledge Sharing: A Review and Directions for Future Research. Human Resource Management Review, 20, 115-131.

Wang, W.-T., Wang, Y.-S., \& Chang, W.-T. (2019). Investigating the Effects of Psychological Empowerment and Interpersonal Conflicts on Employees' Knowledge Sharing Intentions. Journal of Knowledge Management, 1039-1077.

Whitehead, K., Zacharia, Z., \& Prater, E. (2016). Absorptive Capacity Versus Distributive Capability. International Journal of Operations and Production Management, Vol 36, No 10, 1308-1332.

Xie, X., Zou, H., \& Qi, G. (2018). Knowledge absorptive capacity and innovation performance in high-tech companies: A multi-mediating analysis. Journal of Business Research, 88, 289-297.

Yuwono, W. (2021). Empirical Analysis of Intellectual Capital, Potential Absorptive Capacity, Realized Absorptive Capacity, Capacity and . Management Science Letters, 11 (4), 13991406. 
INTERNATIONAL JOURNAL OF ACADEMIC RESEARCH IN BUSINESS AND SOCIAL SCIENCES

Vol. 12, No. 1, 2022, E-ISSN: 2222-6990 @ 2022 HRMARS

Zhao, S., Jiang, Y., Peng, X., \& Hong, J. (2020). Knowledge sharing direction and innovation performance in organizations. European Journal of Innovation Management. 